\title{
The vaginal microbiota of pregnant women who subsequently have spontaneous preterm labor and delivery and those with a normal delivery at term
}

Roberto Romero ${ }^{1,2,3^{*}}$, Sonia S Hassan ${ }^{1,4}$, Pawel Gajer ${ }^{5,6^{*}}$, Adi L Tarca ${ }^{1}$, Douglas W Fadrosh ${ }^{5}$, Janine Bieda ${ }^{1,7}$, Piya Chaemsaithong ${ }^{1}$, Jezid Miranda', Tinnakorn Chaiworapongsa ${ }^{1,4,7}$ and Jacques Ravel ${ }^{5,6}$

\begin{abstract}
Background: This study was undertaken to determine whether the vaginal microbiota of pregnant women who subsequently had a spontaneous preterm delivery is different from that of women who had a term delivery.

Results: This was a nested case-control study of pregnant women who had a term delivery (controls) and those who had a spontaneous preterm delivery before 34 weeks of gestation (cases). Samples of vaginal fluid were collected longitudinally and stored at $-70^{\circ} \mathrm{C}$ until assayed. A microbial survey using pyrosequencing of $\mathrm{V} 1-\mathrm{V} 3$ regions of $16 \mathrm{~S}$ rRNA genes was performed. We tested the hypothesis of whether the relative abundance of individual microbial species (phylotypes) was different between women who had a term versus preterm delivery. A suite of bioinformatic and statistical tools, including linear mixed effects models and generalized estimating equations, was used. We show that: 1) the composition of the vaginal microbiota during normal pregnancy changed as a function of gestational age, with an increase in the relative abundance of four Lactobacillus spp., and decreased in anaerobe or strict-anaerobe microbial species as pregnancy progressed; 2) no bacterial taxa differed in relative abundance between women who had a spontaneous preterm delivery and those who delivered at term; and 3) no differences in the frequency of the vaginal community state types (CST I, III, IV-B) between women who delivered at term and those who delivered preterm were detected.

Conclusions: The bacterial taxa composition and abundance of vaginal microbial communities, characterized with $16 \mathrm{~S}$ rRNA gene sequence-based techniques, were not different in pregnant women who subsequently delivered a preterm neonate versus those who delivered at term.
\end{abstract}

Keywords: Infection-induced preterm delivery, Histologic chorioamnionitis, Prematurity, Vaginal flora, Vaginal microbiome

\section{Background}

Preterm delivery is the leading cause of perinatal morbidity and mortality worldwide [1-8]. There are approximately 15 million preterm births every year $[1,3,8]$, and few approaches have been proven successful to reduce the rate of preterm birth and neonatal morbidity [9-11].

\footnotetext{
* Correspondence: prbchiefstaff@med.wayne.edu; pgajer@gmail.com 'Perinatology Research Branch, Program for Perinatal Research and Obstetrics, Division of Intramural Research, Eunice Kennedy Shriver National Institute of Child Health and Human Development, $\mathrm{NIH}$, Bethesda, MD, USA ${ }^{5}$ Institute for Genome Sciences, University of Maryland School of Medicine, 801 West Baltimore Street, Baltimore, MD 21201, USA

Full list of author information is available at the end of the article
}

The cost of preterm birth to society has been estimated to be more than $\$ 26$ billion per year in the United States alone [12-14]; therefore, the prediction and prevention of preterm birth is a major health care priority.

Of all preterm births, two-thirds occur after the spontaneous onset of preterm labor (with intact or ruptured membranes) [15]. Multiple mechanisms of disease have been implicated in the onset of spontaneous preterm labor (that is, infection/inflammation, uterine overdistension, decidual senescence, and so on). [16,17]. In normal pregnancy, the amniotic cavity is considered 'sterile'; yet, microbial invasion of the amniotic cavity (MIAC), 
often subclinical in nature, occurs in one of every four preterm deliveries [18-20]. Microorganisms and their products can induce a local inflammatory response in gestational tissues (acute chorioamnionitis), leading to preterm labor [18-37]. Most intra-amniotic infections are thought to occur when microorganisms in the lower genital tract (vagina and/or cervix) gain access to the amniotic fluid [17]. Changes in the microbial ecosystem of the vagina have been implicated in the genesis of ascending intrauterine infection [17,20,31,38-45].

Trichomonas vaginalis infection [46-48] and bacterial vaginosis $[28,41,43,49-67]$ are risk factors for spontaneous preterm labor and delivery; yet, identification of the patient with either of these conditions who will subsequently have a preterm delivery has proven difficult [60]. Characterization of the microbial composition of ecological niches in the human body [68-77], including the vagina, using culture-independent techniques, is now possible [78-96]. We previously reported a survey of the microbial communities of the vagina using sequencing of the $16 \mathrm{~S}$ ribosomal RNA (rRNA) gene in normal pregnancy [97]. However, there is no information as to whether changes in the microbial composition of the vagina (using sequence-based techniques) occur prior to the onset of spontaneous preterm delivery.

The purpose of this study was to determine whether the longitudinal vaginal microbiota composition and structure of pregnant women who subsequently had a spontaneous preterm delivery is different from that of women who had a normal spontaneous term delivery. The major findings reported herein are that the vaginal microbiota changes with gestational age in women who deliver at term, and no differences were detected in the bacterial taxa, relative abundance and frequency of community state types between patients who deliver at term and those who subsequently had a spontaneous preterm delivery.

\section{Methods}

\section{Study design}

This was a nested case-control study conducted to compare changes in the vaginal microbiota of patients who had a spontaneous preterm labor and delivery with those who had an uncomplicated pregnancy. Cases and controls were selected in a 1:4 ratio from a prospective longitudinal cohort study designed to examine the relationship between biological markers and pregnancy outcome. The study included 18 cases and 72 controls. Patients with indicated preterm birth (for example, preeclampsia, intrauterine growth restriction, or congenital anomalies) were excluded. Patients volunteered to participate in the study and signed a written informed consent. The use of samples from the longitudinal study of pregnant women was approved by the Human Investigations Committee of Wayne State University and the Institutional Review Board (IRB) of the Eunice Kennedy Shriver National Institute of Child Health and Human Development (NICHD).

\section{Clinical definitions}

A normal pregnant woman was defined as one without obstetrical, medical or surgical complications, who delivered at term (38 to 42 weeks) without congenital anomalies or acute histologic chorioamnionitis. Preterm labor was diagnosed by the presence of at least two uterine contractions every 10 minutes associated with cervical changes in patients with a gestational age between 20 and 34 weeks. Preterm premature rupture of membranes (PPROM) was identified with a sterile speculum examination with documentation of vaginal pooling and positive nitrazine and ferning tests. Spontaneous preterm delivery was defined as having occurred prior to the $34^{\text {th }}$ week of gestation in patients with either intact membranes or PPROM. Acute histologic chorioamnionitis was diagnosed based on the presence of inflammatory cells in the chorionic plate and/or chorioamniotic membranes [98-100]. Sixty-one percent $(11 / 18)$ of the cases had evidence of acute histologic chorioamnionitis.

\section{Study procedures}

Pregnant women who agreed to participate in the study had a speculum examination at each visit; a sample of vaginal fluid was collected under direct visualization from the posterior vaginal fornix by an obstetrician or midwife using a Dacron swab (medical packaging swab - PAK ${ }^{\mathrm{Tn}}$ Carmarillo, CA, USA). The protocol called for sample collection every 4 weeks until 24 weeks of gestation, and then every 2 weeks until the last prenatal visit. Vaginal swabs were placed in a tube without any buffer and immediately stored at $-70^{\circ} \mathrm{C}$ until assayed.

\section{DNA extraction, amplification and pyrosequencing of barcoded V1-V3 hypervariable regions of 16S rRNA genes} Procedures for the extraction of genomic DNA from frozen vaginal swabs have been developed and validated previously [101,95,102]. Briefly, frozen vaginal swabs were immersed in $1 \mathrm{ml}$ of sterile PBS and vortexed for 10 minutes. A total of $500 \mu \mathrm{l}$ of the cell suspension was mixed with $500 \mu \mathrm{l}$ of pre-warmed $\left(55^{\circ} \mathrm{C}\right)$ cell lysis buffer composed of $0.05 \mathrm{M}$ potassium phosphate buffer containing $50 \mu \mathrm{l}$ lyzosyme $(10 \mathrm{mg} / \mathrm{ml}), 6 \mu \mathrm{l}$ of mutanolysin (25,000 U/ml; Sigma-Aldrich, St. Louis, MO, USA) and $3 \mu \mathrm{l}$ of lysostaphin $(4,000 \mathrm{U} / \mathrm{ml}$ in sodium acetate; Sigma-Aldrich) and the mixture was incubated for one hour at $37^{\circ} \mathrm{C}$. Then $10 \mu \mathrm{l}$ proteinase $\mathrm{K}(20 \mathrm{mg} / \mathrm{ml})$, $100 \mu \mathrm{l} 10 \% \mathrm{SDS}$, and $20 \mu \mathrm{l}$ RNase A $(20 \mathrm{mg} / \mathrm{ml})$ were 
added and the mixture was incubated for one hour at $55^{\circ} \mathrm{C}$. The samples were transferred to a FastPrep Lysing Matrix B tube (MP Biomedical, Santa Ana, CA, USA) and microbial cells were lysed by mechanical disruption using a bead beater (FastPrep instrument, Qbiogene, Carlsbad, CA, USA) set at $6.0 \mathrm{~m} /$ second for 30 seconds. The lysate was processed using the CellFree500 kit on a QIAsymphony robotic platform. The DNA was eluted into $100 \mu \mathrm{l}$ of TE (10 mM Tris-HCl, $1 \mathrm{mM}$ EDTA) buffer, $\mathrm{pH}$ 8.0. This procedure provided between 2.5 and $5 \mu \mathrm{g}$ of high quality whole genomic DNA from vaginal swabs.

The bacterial species composition and abundance in vaginal communities were determined using cultureindependent methods. The V1-V3 hypervariable regions of the 16S rRNA gene were amplified using an optimized primer set comprising $27 \mathrm{~F}$ [103] and 534R. Because primer $534 \mathrm{R}$ contains a unique sample identifying barcode, up to 192 samples were sequenced per run and generated 4,000 to 6,000 sequence reads per sample. The primers were as follows:

$27 \mathrm{~F}$ - 5'-GCCTTGCCAGCCCGCTCAGTCAGAGTT TGATCCTGGCTCAG-3'

534R - 5'-GCCTCCCTCGCGCCATCAGNNNNNNN NCATTACCGCGGCTGCTGGCA-3'

The italicized sequences are the 454 Life Sciences ${ }^{\oplus}$ primers $\mathrm{B}$ and $\mathrm{A}$ in $27 \mathrm{~F}$ and $534 \mathrm{R}$, respectively, and the bold font denotes the universal 16S rRNA primers $27 \mathrm{~F}$ and 534R. The barcode within 534R is denoted by eight Ns (but varies from six to eight Ns) and were identical to those used by the Human Microbiome Project [104]. A mixture of bacterial $27 \mathrm{~F}$ primers was used to maximize sequence type discovery and eliminate the PCR amplification bias described by Frank et al. [103]. The $27 \mathrm{~F}$ formulation remains relatively simple: having only seven distinct primer sequences there is minimal loss of overall amplification efficiency and specificity. The $27 \mathrm{~F}$ primer mixture was: four parts of four-fold-degenerate primer 27f-YM (5'-AGAGTTTGATYMTGGCTCAG, where Y is C or T) plus one part each of primers specific for the amplification of Bifidobacteriaceae (27f-Bif, 5' -AGGGTTCGATTCTG GCTCAG), Borrelia (27f-Bor, 5' -AGAGTTTGATCC TG GCTTAG), and Chlamydiales (27f-Chl, 5'-AGAATTTGA TCTTGGTTCAG) sequences. This primer formulation was previously shown to better maintain the original rRNA gene ratio of Lactobacillus spp. to Gardnerella spp. in quantitative PCR assays, particularly under stringent amplification conditions [103].

For every set of 192 vaginal genomic DNA samples, PCR amplification of $16 \mathrm{~S}$ rRNA genes was performed in 96-well microtiter plates as follows: $1 \times$ PCR buffer, $0.3 \mu \mathrm{M}$ primer $27 \mathrm{~F}$ and 534R, $0.25 \mu \mathrm{l}$ HotStar HiFidelity DNA polymerase (5 U/ $\mu \mathrm{l}$; Qiagen, Germantown, MD), and $25 \mathrm{ng}$ of template DNA in a total reaction volume of $25 \mu \mathrm{l}$. Reactions were set up on a QIAgility robotic platform in a semi-sterile environment. Reactions were run in a DNA engine Tetrad2 instrument (Bio-Rad, Hercules, CA) using the following cycling parameters: 5 minutes denaturing at $95^{\circ} \mathrm{C}$ followed by 29 cycles of 30 seconds at $94^{\circ} \mathrm{C}$ (denaturing), 30 seconds at $52^{\circ} \mathrm{C}$ (annealing) and 60 seconds at $72^{\circ} \mathrm{C}$ (elongation), with a final extension at $72^{\circ} \mathrm{C}$ for 10 minutes. Separate plates containing negative controls without a template for each of the 96 barcoded primers were included for each set of plates processed: in our workflow, if one of these samples is positive, the samples and negative controls plates are rerun with new primers; however, no amplicons were observed in any of the no template controls. The presence of amplicons was confirmed by gel electrophoresis on a $2 \%$ agarose gel stained with SYBRGreen (Life Technologies, Carlsbad, CA, USA). PCR products were quantified using the Quant-iT Picogreen ${ }^{\circ}$ quantification system (Life Technologies) and equimolar amounts (100 ng) of the PCR amplicons were mixed in a single tube using the QIAgility robotic platform. Amplification primers and reaction buffer were removed by processing the amplicon mixture with the Agencourt AMPure Kit (Beckman-Coulter, Pasadena, CA, USA). All PCR amplification reactions that failed were repeated twice using different amounts of template DNA, and if these failed, the samples were excluded from the analysis.

The purified amplicon mixtures were sequenced by 454 pyrosequencing using 454 Life Sciences $^{\oplus}$ (Roche/454 Life Sciences, Branford, CT) primer A by the Genomics Resource Center at the Institute for Genome Sciences, University of Maryland School of Medicine, using Roche/ 454 Titanium chemistries and protocols recommended by the manufacturer and amended by the Center.

All sequences were trimmed before the first ambiguous base pair. The QIIME software package [105] was used for quality control of the sequence reads using the split-library.pl script and the following criteria: 1) minimum and maximum length of $250 \mathrm{bp}$ and $450 \mathrm{bp}$; 2) an average of q25 over a sliding window of $25 \mathrm{bp}$. If the read quality dropped below q25, it was trimmed at the first base pair of the window then reassessed for length criteria; 3 ) a perfect match to a barcode sequence; and 4) presence of the 534R $16 \mathrm{~S}$ primer sequence used for amplification. Sequences were binned based on sample-specific barcode sequences and trimmed by removal of the barcode and primer sequences (forward, if present, and reverse). High-quality sequence reads were first de-replicated (99\% similarity) using the UCLUST software package [106]. Detection of potential chimeric sequences was performed using the UCHIME component of UCLUST [107] with the de novo algorithm. Chimeric sequences were removed prior to taxonomic assignments. Taxonomic assignments were performed on each individual quality checked $16 \mathrm{~S}$ rRNA 
sequence read using a combination of pplacer [108] and speciateIT (speciateIT.sourceforge.net). Taxonomic assignments (sequence read counts and relative abundances) are shown in Additional file 1: Table S1. All sequence data and metadata were deposited in the Sequence Read Archive (SRA; http://www.ncbi.nlm.nih.gov/Traces/sra/) under BioProject PRJNA242473 (SRA accession SRA150182, SRP040750).

\section{Statistical analysis}

The abundance of bacteria is generally expressed on a logarithmic scale (base 10), given the wide range of bacterial abundance and the exponential nature of bacterial growth under certain circumstances (for example in vitro). The standard is to compare microbial abundance over time using the difference of $\operatorname{logs}, \log _{10}$ (a) $-\log _{10}$ (b), which is the same as the log fold change $\log _{10}(a / b)$, where $a$ and $b$ are relative abundances of a given microorganism in two samples (for example, two sampling time points).

Changes in the abundance of a complex microbial ecosystem within the same patient at different time points were estimated for specific phylotypes. We assessed the dissimilarity between community states (in other words, how divergent community states are) using the JensenShannon metric [109]. In microbial ecology, the term 'community state' refers to the relative abundance of all phylotypes at a particular time point in a subject; in our case, a sample of vaginal fluid.

The Jensen-Shannon divergence between two community states, $\mathrm{p}$ and $\mathrm{q}$, is the average of the Kullback-Leibler divergences $D_{K L}(p, a)$ and $D_{K L}(q, a)$ :

$$
D_{J S}(p, q)=\frac{D_{K L}(p, a)+D_{K L}(q, a)}{2}
$$

where $a$ is the mean of $p$ and $q$ and $\mathrm{D}_{\mathrm{KL}}(\mathrm{p}, \mathrm{q})$ is the Kullback-Leibler divergence defined as:

$$
\mathrm{D}_{\mathrm{KL}}(\mathrm{p}, \mathrm{q})=\sum_{i=1}^{n} P_{i} \log \left(\frac{P_{i}}{q_{i}}\right)
$$

where $\mathrm{p}=\left(\mathrm{p}_{1}, \ldots, \mathrm{p}_{\mathrm{n}}\right)$ and $\mathrm{q}=\left(\mathrm{q}_{1}, \ldots, \mathrm{q}_{\mathrm{n}}\right)$.

The Kullback-Leibler divergence $D_{K L}(p, q)$ calculates the mean $\log$ fold changes $\log \left(\mathrm{p}_{\mathrm{i}} / \mathrm{q}_{\mathrm{i}}\right)$. While the Kullback-Leibler measure is widely used, it has one drawback: its value becomes infinite if one of the components of $\mathrm{q}$ is zero. In contrast, the Jensen-Shannon divergence always yields a value between 0 and 1 . A Jensen-Shannon divergence score of 0 means that two community states are the same. In contrast, a Jensen-Shannon divergence score of 1 means that the two community states are completely different. The square root of the Jensen-Shannon divergence is called 'Jensen-Shannon distance.'
The term 'community state type' is used in microbial ecology to describe a group of community states with similar microbial phylotype composition and abundance $[95,110]$. Such grouping is desirable in order to reduce dimensionality. Utilizing Jensen-Shannon divergence as a measure of dissimilarity among community states and hierarchical clustering with Ward linkage, six vaginal community state types in pregnant and non-pregnant women have been previously identified [95,97]. Four of the community state types (I, II, III and V) are dominated by Lactobacillus spp. (Lactobacillus crispatus, L. gasseri, L. iners, and L. jensenii, respectively) and the remaining two community state types (IV-A, IV-B) consist of microbial ecosystems with a diverse array of anaerobes and strict anaerobes, and substantially lower numbers of Lactobacillus spp. than the other community state types.

\section{Statistical procedures to evaluate the differential} abundance of phylotypes between women who deliver at term and those who had a spontaneous preterm delivery In order to assess a change in phylotype relative abundance between the two groups, we modeled the relative abundance of one phylotype at a time as a function of study group (that is, normal pregnancy versus spontaneous preterm delivery). Only phylotypes present (one read count) in $25 \%$ or more of the samples were considered in the analysis.

Read count data obtained from a longitudinal experiment design are typically modeled using generalized estimation equations (GEE) or linear mixed-effects (LME) models by assuming a Poisson or negative binomial distribution of the response. The choice of a Poisson distribution is justified when the count variance equals the count mean, while the negative binomial distribution is preferred when the mean-variance equality cannot be safely assumed.

Several phylotypes were not detected in a large proportion of samples; hence, the frequency of 0 count values in the dataset was larger than expected under a Poisson or negative binomial distribution. Therefore, models that allow for zero inflation are more appropriate; indeed, this approach has been used for decades [111].

To ensure a proper fit of the count data of each phylotype, we utilized zero-inflated negative binomial mixed-effects models (ZINBLME) in addition to negative binomial linear mixed effects (NBLME) and Poisson linear mixed effects (PLME) models. These three types of models were fitted to each phylotype, and the model with the lowest Akaike Information Criterion (AIC) value was retained. The $P$-value for the association between the microbial relative abundance and the group variable was computed only for the best model (smallest AIC). 
The mixed effects modeling of the read counts data (dependent variable) on pregnancy status (independent variable) was performed using the NLMIXED procedure in SAS (version 9.3) as discussed elsewhere [97,112,113]. All three types of models (PLME, NBLME and ZINBLME) included an offset term (the log of the total number of reads in a given sample) to allow for a comparison of the relative abundance (and not absolute counts) between groups. The random effect in the ZINBLME models was allowed only on the non-zero inflation component (negative binomial mean).

For each of the three types of models, the reported coefficient represents the difference in mean log relative abundance between patients who subsequently had a spontaneous preterm delivery and those who delivered at term, which was further converted into a fold change. The $P$-value of the model with the best fit (smallest AIC) was retained and false discovery rate adjustment was applied across the phylotypes. A q-value $<0.1$ and fold change $>1.5$ were considered significant.

\section{Analytical approach to examine changes in abundance of phylotypes with gestational age}

The approach used to identify phylotypes associated with spontaneous preterm delivery, described above, was also used to characterize changes in the phylotypes' abundance as a function of gestational age. The gestational age range over which samples were obtained in this longitudinal study of pregnant women who deliver at term was divided into three intervals: 6.9 to $22.1,22.2$ to 29.8 and 29.9 to 41 weeks. The two cut-off points at 22.1 and 29.8 weeks were selected so that the resulting three intervals had comparable gestational age windows and a comparable number of vaginal samples. The 5th and 95th percentiles of the gestational age over which samples were collected, were calculated. Then, the interval between the 5th and 95th percentile was divided into three gestational age windows (14.5 to 22.1 weeks, 22.2 to 29.8 weeks and 29.9 to 37.5 weeks).

This analysis provides a simple description of the gestational age-related trends in microbial abundance (for example, an increase in abundance of approximately two fold from the first to second interval). However, such an approach may not capture potentially more complex trends in the microbial abundance as a function of gestational age. Therefore, a secondary analysis was performed by treating gestational age as a continuous variable. Orthogonal polynomial terms based on gestational age were used as explanatory variables in a NBLME model. The response variable in this model was the observed number of reads for each phylotype in each sample. The degree of the polynomial function was selected so that the resulting model minimized the AIC criterion. The degree of the polynomial function varied from 1 to 7 . The $P$-values for the between intervals' comparisons as well as the $P$-value for each polynomial term were adjusted across phylotypes. A false discovery rate of $10 \%$ was used.

\section{Results}

\section{Characteristics of the study population}

The clinical and demographic characteristics of pregnant women who had a term delivery or a spontaneous preterm delivery are displayed in Table 1 . The median number (interquartile range, IQR) of samples for term and preterm deliveries was 4 (2 to 6) and 3 (2 to 4 ), respectively, for a total of 349 samples. There were no significant differences in the age, race, pre-pregnancy body mass index and nulliparity between the groups (all $P>0.05)$. As expected, preterm neonates had lower birthweights and Apgar scores than term neonates (Table 1).

\section{Characterization of the microbial taxa as a function of depth of coverage}

We characterized the vaginal microbiota using pyrosequencing of barcoded 16S RNA genes. The data set consisted of 2,639,039 high quality sequences, with a median length of 433 bp (IQR: 391 to 475). The median number of sequences per sample was 7,548 (IQR: 5,388 to 9,489). Taxonomic assignment of the individual sequence reads identified a total of 99 taxa in the vaginal microbiota of the women studied; all 99 taxa were observed both in pregnant women who delivered preterm and in those who delivered at term. The taxonomic assignment of vaginal bacterial community members is shown in Additional file 1: Table S1.

\section{The vaginal microbiota of women who deliver preterm versus those who deliver at term}

Our attempt to identify phylotypes with relative abundances that were significantly different between women who delivered at term and those with spontaneous preterm delivery was based on statistical models appropriate for the type of data generated and that: 1) were designed for count data modeling (assuming Poisson and negative binomial distributions); and 2) allowed for correlated observations from the same individual (for example, linear mixed effect models); while 3) allowing for extra zeroes in the data since some phylotypes were frequently undetected. Only phylotypes that were present in at least $25 \%$ of all samples were included in the analysis, restricting the number of phylotypes to 21 (Additional file 2: Figure S1).

Table 2 shows the AIC statistics for all three types of models for each phylotype, as well as the estimate, confidence interval and $P$-value for the best (smallest AIC) model. These analyses did not reveal any differences in the relative abundance of bacterial phylotypes between women who delivered preterm and those who delivered at 
Table 1 Clinical and demographic characteristics of the study population

\begin{tabular}{|c|c|c|c|}
\hline & Term delivery $(n=72)$ & Spontaneous preterm delivery $(n=18)$ & $P$ value \\
\hline Age (years) & $24(21.8-28)$ & $21(20-26)$ & 0.1 \\
\hline \multicolumn{4}{|l|}{ Race: } \\
\hline African American & $62(86.1 \%)$ & $17(94.4 \%)$ & 0.7 \\
\hline White & $4(5.6 \%)$ & $1(5.6 \%)$ & \\
\hline Others & $6(8.3 \%)$ & 0 & \\
\hline Pre-pregnancy BMI $\left(\mathrm{kg} / \mathrm{m}^{2}\right)$ & $28.7(25.7-35.3)^{*}$ & $25.7(21.6-33.6)^{* *}$ & 0.2 \\
\hline Nulliparity & $18(25 \%)$ & 7 (38.9\%) & 0.3 \\
\hline Gestational age at delivery (weeks) & $39.6(38.8-40.7)$ & $30.5(28-33.1)$ & 0.001 \\
\hline Birthweight (grams) & 3295 (3124.3-3538.8) & $1402.5(997.5-1998.8)$ & 0.001 \\
\hline Apgar score at $1 \mathrm{~min}$ & $9(8-9)$ & $6(3-8)$ & 0.001 \\
\hline Apgar score at 5 min & $9(9-9)$ & $8(6-8)$ & 0.001 \\
\hline Duration of hospital stay (neonates); in days & $3(3-3)^{* *}$ & $26(13-53)^{* * *}$ & 0.001 \\
\hline
\end{tabular}

Data presented as median (interquartile range) or $\mathrm{n}(\%)$

BMl: body mass index.

Missing data: ${ }^{*} n=4,{ }^{* *} n=6,{ }^{* * *} n=1$.

Table 2 Phylotypes differential relative abundance between pregnant women who delivered preterm and at term

\begin{tabular}{|c|c|c|c|c|c|c|c|c|c|c|}
\hline Phylotypes & $\begin{array}{l}\text { PLME } \\
\text { AIC }^{\mathrm{a}, \mathrm{d}}\end{array}$ & $\begin{array}{l}\text { NBLME } \\
\text { AIC }^{\mathbf{b}, \mathrm{d}}\end{array}$ & $\begin{array}{l}\text { ZINBLME } \\
\text { AIC }^{c, d}\end{array}$ & $\begin{array}{l}\text { Best } \\
\text { AIC }^{\text {d }}\end{array}$ & Estimate & Lower $95 \% \mathrm{Cl}$ & Upper $95 \% \mathrm{Cl}$ & Fold change & $p$-value & q-value ${ }^{e}$ \\
\hline \multicolumn{11}{|l|}{$\begin{array}{l}\text { Non-significantly different } \\
\text { phylotypes }\end{array}$} \\
\hline Prevotella genogroup 3 & 6017.7 & NA & 1160.3 & ZINBLME & 2.524 & 0.341 & 4.706 & 12.5 & 0.0239 & 0.3850 \\
\hline Dialister sp. type 2 & 3934.3 & 4142.6 & 1346.3 & ZINBLME & 1.630 & -0.002 & 3.261 & 5.1 & 0.0502 & 0.3850 \\
\hline Sneathia sanguinegens & 2875.4 & NA & 1121.2 & ZINBLME & 1.510 & -0.033 & 3.053 & 4.5 & 0.0550 & 0.3850 \\
\hline Parvimonas micra & 4338.8 & NA & 1242.3 & ZINBLME & 1.339 & -0.458 & 3.136 & 3.8 & 0.1422 & 0.5972 \\
\hline Gemella & 4753.1 & NA & 1296.3 & ZINBLME & 1.327 & -0.225 & 2.879 & 3.8 & 0.0927 & 0.4867 \\
\hline BVAB2 & 12246 & NA & 1686.4 & ZINBLME & 1.129 & -0.784 & 3.041 & 3.1 & 0.2440 & 0.7046 \\
\hline Lactobacillus jensenii & 54150 & NA & 2859 & ZINBLME & 1.040 & -0.518 & 2.597 & 2.8 & 0.1880 & 0.6580 \\
\hline BVAB1 & 116789 & NA & 2467.9 & ZINBLME & 0.915 & -0.976 & 2.807 & 2.5 & 0.3389 & 0.7046 \\
\hline Megasphaera sp. type 1 & 38178 & NA & 2860.1 & ZINBLME & 0.717 & -0.864 & 2.298 & 2.0 & 0.3700 & 0.7046 \\
\hline Dialister propionicifaciens & 3433.2 & 4330.8 & 1529.3 & ZINBLME & 0.625 & -0.738 & 1.987 & 1.9 & 0.3648 & 0.7046 \\
\hline $\begin{array}{l}\text { Lactobacillus } \\
\text { coleohominis }\end{array}$ & 2309.1 & NA & 1405.6 & ZINBLME & 0.550 & -0.800 & 1.899 & 1.7 & 0.4206 & 0.7046 \\
\hline Gardnerella vaginalis & 193277 & 166894 & 4311.4 & ZINBLME & 0.520 & -0.961 & 2.000 & 1.7 & 0.4874 & 0.7046 \\
\hline Aerococcus christensenii & 18185 & 17841 & 2505.6 & ZINBLME & 0.383 & -1.107 & 1.872 & 1.5 & 0.6108 & 0.7987 \\
\hline Atopobium vaginae & NA & NA & 2625.8 & ZINBLME & 0.376 & -1.249 & 2.001 & 1.5 & 0.6466 & 0.7987 \\
\hline Lactobacillus crispatus & 159892 & 125388 & 3788 & ZINBLME & 0.157 & -1.784 & 2.098 & 1.2 & 0.8724 & 0.9068 \\
\hline Lactobacillus iners & 263630 & 194492 & 6324.8 & ZINBLME & 0.045 & -0.721 & 0.811 & 1.0 & 0.9068 & 0.9068 \\
\hline Eggerthella & 2926.9 & NA & 1405.3 & ZINBLME & -0.189 & -1.724 & 1.345 & -1.2 & 0.8069 & 0.8918 \\
\hline Lactobacillus vaginalis & 2682.8 & NA & 1149.1 & ZINBLME & -0.293 & -1.940 & 1.354 & -1.3 & 0.7248 & 0.8456 \\
\hline Ureaplasma parvum & 1866.8 & NA & 1184.9 & ZINBLME & -0.374 & -1.480 & 0.732 & -1.5 & 0.5033 & 0.7046 \\
\hline Atopobium rimae & 1386.9 & NA & 883.8 & ZINBLME & -0.522 & -1.910 & 0.865 & -1.7 & 0.4567 & 0.7046 \\
\hline Lactobacillus gasseri & 34741 & NA & 1592.4 & ZINBLME & -0.864 & -2.847 & 1.118 & -2.4 & 0.3887 & 0.7046 \\
\hline
\end{tabular}

PLME: Poisson Linear Mixed Effects Model.

${ }^{\mathrm{b}}$ NBLME: Negative Binomial Linear Mixed Effects.

'ZINBLME: Zero-Inflated Negative Binomial Mixed-Effects Model.

${ }^{d}$ AIC: Akaike Information Criterion.

${ }^{e} \mathrm{q}$-value is $\mathrm{p}$-value after adjustment for false-discovery rate $(0.1)$. 
term. In addition, among women who had a spontaneous preterm delivery, we did not find differences in the relative abundance of bacterial phylotypes between women with and without acute histologic chorioamnionitis.

\section{Dynamic changes in vaginal microbiota as a function of gestational age}

To examine whether the vaginal microbiota changes with gestational age, we focused on women with a normal pregnancy who delivered at term $(n=72)$. We tested this hypothesis by categorizing gestational age into three intervals and also by treating gestational age as a continuous variable in linear mixed-effects models. Based on the analysis in which the gestational age was categorized in three intervals, we found that the relative abundance of four Lactobacillus spp. (L. crispatus, L. jensenii, L. gasseri and L. vaginalis) increased as a function of gestational age. Indeed, the mean relative abundance in the third interval (29.9 to 41 weeks) was higher than in the first interval (6.9 to 22.1 weeks) of gestation (q-value <0.1) (Additional file 3: Figure S2 and Additional file 4: Table S2). The relative abundance of eleven other bacterial taxa was found to decrease with advancing gestational age. These included: Eggerthella, Parvimonas micra, Dialister spp. type 2, Gemella, bacterial vaginosis associated bacteria 1 (BVAB1), BVAB2, Atopobium vaginae, Gardnerella vaginalis, Atopobium rimae, Sneathia sanguinegens and Ureaplasma parvum. A separate analysis in which gestational age was treated as a continuous variable confirmed all positive findings from the three-interval based approach (Additional file 5: Table S3).

\section{Vaginal microbial community structures in women who delivered at term and those who had a spontaneous preterm delivery}

In order to visualize the structure of the microbial community of the vaginal ecosystem in pregnant women who delivered at term versus those who delivered preterm, we hierarchically clustered the vectors of relative abundances of bacterial phylotypes (one per sample) using the Jensen-Shannon metric and Ward linkage [110]. In this study, a 'community state' refers to a vector of relative abundances of bacterial phylotypes for a given sample. Community states clustered into three groups with similar bacterial composition and abundance (Figure 1), referred to as community state types (CST), according to the nomenclature established by Gajer et al. [110].

Two of these CSTs were most often dominated by $L$. crispatus (CST I) and L. iners (CST III). Communities that clustered in CST IV-B lacked a substantial number of Lactobacillus spp. and had higher relative abundance of G. vaginalis, BVAB1, A. vaginae and Megasphaera spp. type 1 . These taxa have been previously shown to be associated with bacterial vaginosis $[80,83,114]$.
Overall, frequencies of CST I, CST III and CST IV-B in the entire sample set were $18.6 \%, 58.5 \%$ and $22.9 \%$, respectively. There were no differences in the frequency of the different CSTs (CST I, III, IV-B) between women who delivered at term and those who delivered preterm (CST I: $18.4 \%$ versus $19.6 \%$; CST III: $59.4 \%$ versus $53.6 \%$; CST IV-B: $22.2 \%$ versus $26.8 \%$ ). Longitudinal profiles of CSTs as a function of gestational age and per subject are shown in Figure 2.

A comparison of microbial diversity (Shannon Diversity Index; SDI) between women who had a spontaneous preterm delivery and those who had a term delivery was performed using a LME model. The SDI values were log-transformed to improve normality of the data. No differences in the microbial diversity were found (term delivery: SDI median 0.38; IQR 0.12 to 1.03 ; preterm delivery: SDI median 0.39; IQR 0.08 to 1.04 ).

\section{Discussion}

\section{Principal findings of the study}

The study's principal findings are as follows: 1) the composition of the vaginal microbiota during normal pregnancy changes as a function of gestational age, with an increase in the relative abundance of four Lactobacillus spp., and a decrease in anaerobe or strict-anaerobe microbial species as pregnancy progresses; 2) there were no differences in the relative abundance of microbial phylotypes between women who had a spontaneous preterm delivery and those who delivered at term; and 3) no differences were observed in the frequency of the vaginal CSTs (CST I, III, IV-B) between women who delivered at term or preterm.

\section{The vaginal microbiota of normal pregnant women}

A companion study [97] examined the vaginal microbiota in 22 pregnant women, and compared phylotype abundance and the stability of the microbiota with that of 32 non-pregnant women. The larger sample size of the current study allowed us to demonstrate that there are changes in the vaginal microbiota as a function of gestational age. The abundance of 16 taxa was found to change with the duration of pregnancy; of those, four increased (L. crispatus, L. jensenii, L. gasseri and L. vaginalis) and eleven decreased (Eggerthella, P. micra, Dialister spp. type 2, Gemella, BVAB1, BVAB2, A. vaginae, G. vaginalis, $A$. rimae, $S$. sanguinegens and $U$. parvum). An interesting finding is that all of the phylotypes that increased in abundance belonged to the genus Lactobacillus, while those that decreased were anaerobes. Of note, L. iners, the most prevalent Lactobacillus spp. in the vaginal microbiota [95], was among six phylotypes (Prevotella genogroup 3, D. propionicifaciens, Megasphaera spp. type 1, A. christensenii and L. coleohominis) for which the relative abundance did not change significantly between 


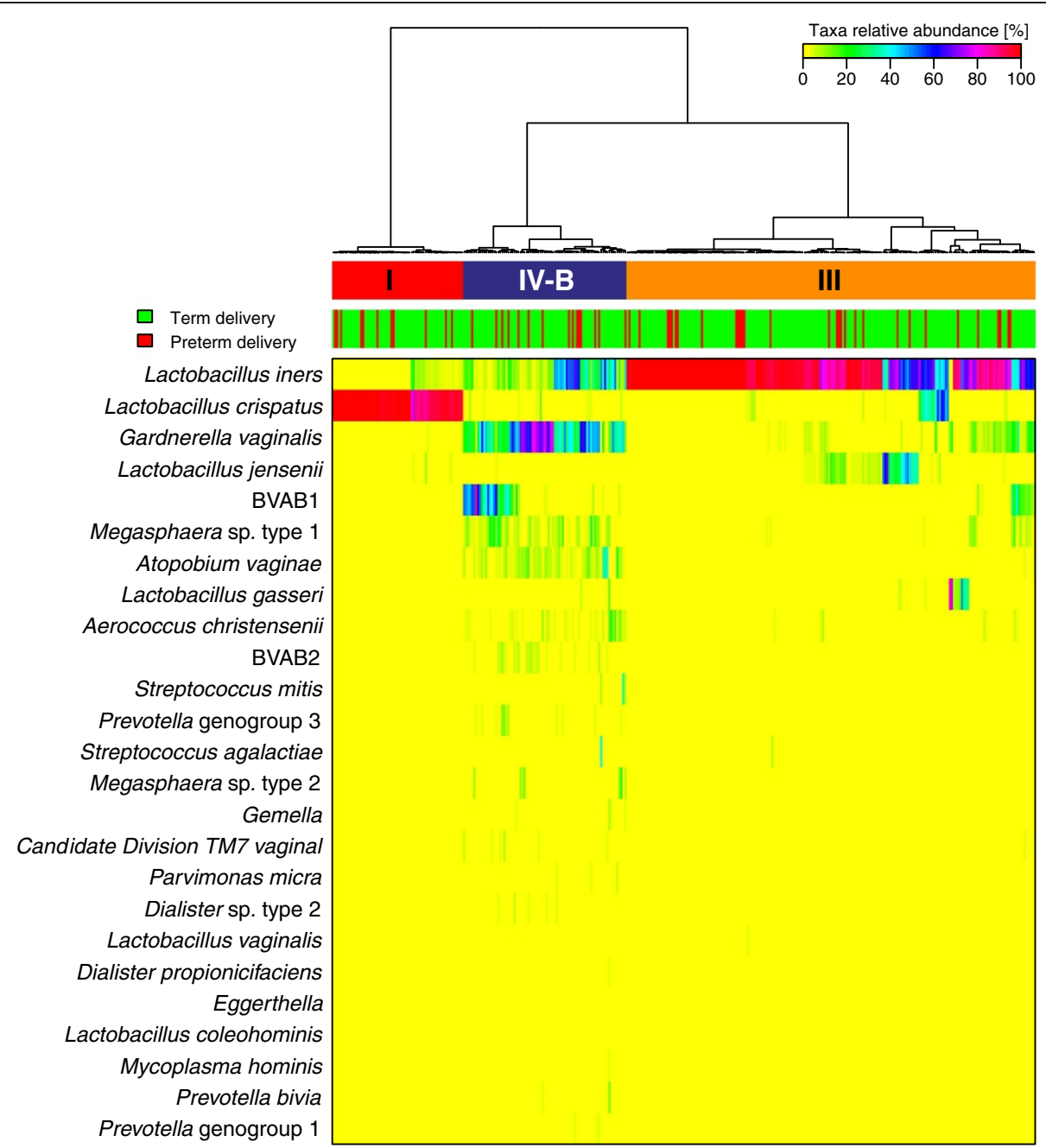

Figure 1 Heatmap of microbial taxa relative abundance identified in the vaginal microbiota of women who delivered at term and women who delivered preterm. Ward linkage clustering of samples based on the composition and relative abundance of the 25 most abundant species in the vaginal microbiota that define community state types is shown above the heatmap.

the two groups of pregnant women (Additional file 3: Figure S2).

These observations are relevant to understanding the changes in the vaginal ecosystem with normal pregnancy. Moreover, it is possible that these temporal changes may be meaningful in assessing health and predisposition to disease states. Comparison of the current results with culture-based studies in pregnancy is difficult because sequence-based techniques allow the comprehensive detection of bacteria and assessment of their abundance, which may not be possible with standard cultivation methods.

\section{The vaginal microbiota of women at risk for preterm delivery}

A compelling body of evidence supports a causal association between intra-amniotic infection and spontaneous preterm delivery [18-24,26,29,33,34,36,115,116].
The organisms found in the amniotic cavity are often similar taxonomically to those found in the lower genital tract of pregnant women as demonstrated by using both cultivation and molecular techniques $[19,23,25,40,42,48,54,117-120]$. Therefore, an ascending pathway has been proposed to be the most frequent cause of intra-amniotic infection $[19,20,38,39,44,45]$.

During the last three decades, accumulating evidence has suggested that changes in the microbial ecosystem of the lower genital tract, often referred to as bacterial vaginosis, atypical or aerobic vaginitis $[63,65,121,122]$, are risk factors for spontaneous abortion [123-128], spontaneous preterm delivery [41,49,51-54,56,58-63,65,94,128-131], intra-amniotic infection [28,31,32,35,40,132-135], puerperal endometritis [58,129,136-139] and adverse perinatal outcomes [40,49, $128,131,140-142]$. Even though bacterial vaginosis confers risk for spontaneous preterm delivery, the risk is modest, and most women with this condition will deliver at term. 


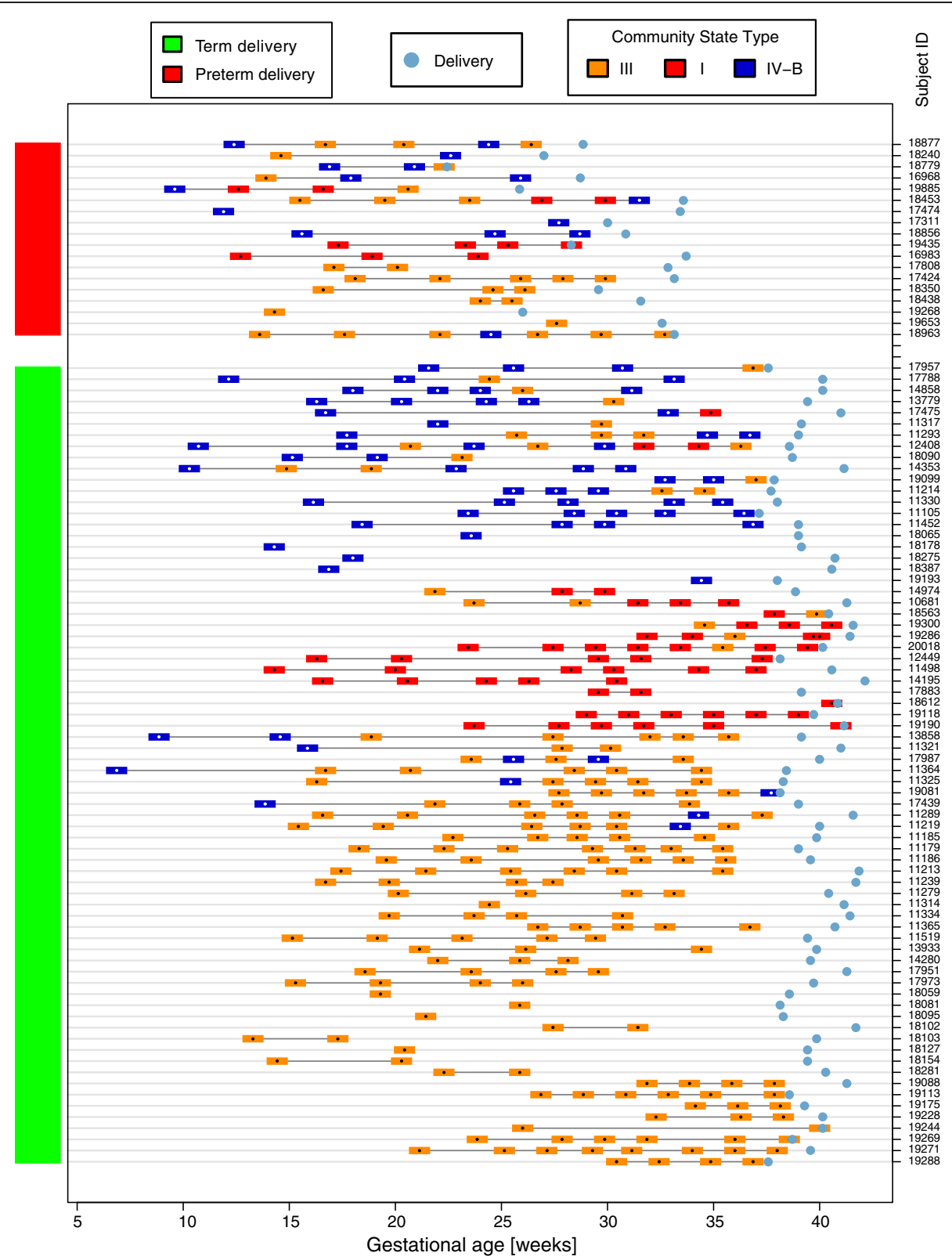

Figure 2 Profiles of community state types for women who delivered at term and women who delivered preterm as a function of the gestational age. Each sample in the longitudinal series was assigned to community state types as defined in Figure 1 and is indicated by a rectangle colored according to the legend shown above. Time of delivery is depicted by a light blue circle.

Most of the evidence suggests that treatment of bacterial vaginosis with antimicrobial agents (metronidazole or clindamycin) during pregnancy does not reduce the rate of preterm delivery [143-148], and this has been attributed to an inadequate characterization of the changes in the microbial ecosystem of the lower genital tract in patients who subsequently delivered preterm or to gene-environment interactions in susceptible individuals [60,61,149-151].

\section{Vaginal microbiota of pregnant women who have a spontaneous preterm delivery}

The present study was undertaken to address the question of whether the vaginal microbial composition of women destined to deliver preterm is different from that of women who deliver at term, using sequence-based techniques (16S rRNA gene surveys) and samples collected throughout pregnancy in both groups. Using a thorough statistical approach that was appropriate for longitudinally-collected 
samples, we did not find any bacterial taxa for which the relative abundance was different in patients who delivered preterm than those who delivered at term.

This study did not identify specific bacteria with an increased or decreased relative abundance that were associated with spontaneous preterm delivery. It is important to note that $61 \%$ of patients who had a spontaneous preterm delivery had acute histologic evidence of chorioamnionitis, which is considered an indicator of the 'amniotic fluid infection syndrome' [152]. Therefore, by design, this study maximized the likelihood of finding changes in the vaginal microbiome in patients who had a spontaneous preterm delivery.

Although one of every four cases of spontaneous preterm labor is associated with microbiologically-proven intra-amniotic infection, it is unclear whether such patients can be identified by the change in the composition and stability of the vaginal microbiota. Changes may be demonstrable in other biological fluids, such as cervical fluid [153]. Assessment of risk for preterm labor/delivery may also require evaluation of the microbial-host interactions (that is, microbial composition, genotype of the host, and the nature of the cellular or soluble immune response). It is possible that the perturbation of the vaginal microbiome leading to intra-amniotic infection is transient and, therefore, difficult to detect using the sample frequency employed in the current study. Characterization of the vaginal microbiota using $16 \mathrm{~S}$ rRNA gene sequence analysis, while very informative in identifying differences in composition, does not provide information on the functions of individual bacteria or the community in the vagina. Comparative metagenomic analysis (sequencing and comparing the genes and genomes of microbial communities) might identify vaginal bacteria of the same species but with a different genomic makeup (carry different metabolic or biochemical pathways) that $16 \mathrm{~S}$ rRNA gene sequence analysis cannot distinguish [154]. In addition, comparative metatranscriptomics (sequencing and comparing the suites of genes expressed by members of microbial communities) might detect functions differentially expressed in women who delivered preterm or at term.

\section{Strengths and limitations}

The major strengths of this study are: 1) its longitudinal nature, which allows characterization of the vaginal microbiota over time, prior to spontaneous preterm birth; 2) the quality of the sequence-based techniques (16S rRNA gene) which reduced bias over other methods, including cultivation techniques; 3) the use of analytical and statistical methods specifically designed for the analysis of longitudinal studies; and 4) the definition of preterm delivery was $<34$ weeks of gestation, minimizing the potential confounding with patients who delivered near term ( $<37$ weeks).
Potential limitations of the study include the sample size. There were 18 patients who had a spontaneous preterm delivery. Yet, this is one of the first studies to address the research question using $16 \mathrm{~S}$ rRNA gene sequence-based techniques. Our report focuses on relative abundance of different community members because it is difficult to interpret bacterial load quantification data from 16S rRNA gene quantitative PCR analysis. Recently, Nelson et al. [155] reported that among women reporting a prior preterm delivery, those with higher levels (absolute abundance) of Leptotrichia/Sneathia species, BVAB1 and Mobiluncus spp. as determined using targeted quantitative PCR, prior to 16 weeks gestation, were significantly more likely to experience a spontaneous preterm delivery. These findings were different from those of Wen et al. [156], who found that the presence of Mycoplasma in the second semester of pregnancy was associated with increased risks of preterm delivery, while the presence of BVAB3 drastically decreases the risk of preterm delivery (however, this was only the case in African American and Hispanic women, but not in Caucasians). We did not find the relative abundance of these taxa to be associated with the vaginal microbiota of women who delivered preterm. Additional studies on the changes in the vaginal microbiome and spontaneous preterm birth are needed. It would be important to characterize the composition of the vaginal microbiota using indices of relative abundance, as well as the overall bacterial absolute abundance.

Although a $16 \mathrm{~S}$ rRNA gene-based survey of microbial communities is a powerful tool to characterize the composition of a microbial community, this approach provides limited information about the function and role of the vaginal microbial community in health and disease. The use of a metagenomic and meta-transcriptomics approach would add considerable information to the one presented in this study, as would studying the nature of the host immune, endocrine and metabolic responses associated with changes in microbial composition.

\section{Conclusions}

We report that the composition of the vaginal microbiota during normal pregnancy changed as a function of gestational age, with an increase in the relative abundance of four Lactobacillus spp., and decreased in anaerobe or strictanaerobe microbial species as pregnancy progressed. Differences in the human vaginal microbiota between women who subsequently had a spontaneous preterm delivery and those who delivered at term were not detected.

\section{Additional files}

Additional file 1: Table S1. Taxonomic assignments, relative abundance of $16 \mathrm{~S}$ rRNA gene sequences per taxa, and metadata. 
Additional file 2: Figure S1. Relative abundance of all phylotypes present in $25 \%$ of all longitudinal samples collected from women who delivered at term (blue) and women who delivered preterm without chorioamnionitis (orange) and with chorioamnionitis (red). The Y-axis represents the percent relative abundance of each taxa in a sample, and the $X$-axis represents each women.

Additional file 3: Figure S2. Changes in phylotype relative abundance as a function of gestational age in women who had a term delivery and evaluated with a three-interval-based analysis. The Y-axis represents the log relative abundance of a given taxa while the $x$-axis is the gestational age at sampling. Each point represents a sample. The two grey vertical dashed lines define three-intervals of gestation. The solid black line represents the mean relative abundance estimated from the Negative Binomial Linear Mixed Effects model, while the dashed curves represent the $95 \%$ confidence interval around the prediction. The arrows at the top of each panel indicate which of the three 'between-interval' comparisons was significant. The direction of change, which is marked above each arrow, with the words 'up' or 'down', indicates the increase/decrease in relative abundance with advancing gestational age from the interval at the left end of the arrow to the interval at the right end of the arrow. A red frame represents phylotypes whose relative abundance significantly increased with gestational age, while a blue frame represents phylotypes whose relative abundance significantly decreased with gestational age. A teal frame represents phylotypes whose relative abundance did not change significantly with gestational age.

Additional file 4: Table S2. Phylotypes whose relative abundance changes as a function of increasing gestational age. Results from the three intervals-based analysis.

Additional file 5: Table S3. Statistical significance of phylotypes whose relative abundance increased or decreased as a function of gestational age (GA) and evaluated with a three intervals-based analysis of GA or a polynomial-based analysis where GA is treated as a continuous variable.

\section{Abbreviations}

AIC: Akaike Information Criterion; bp: base pair; BVAB: bacterial vaginosis associated bacteria; CST: community state type; GEE: generalized estimation equation; IQR: interquartile range; LME: linear mixed-effects; NBLME: negative binomial linear mixed effect; NIH: National Institutes of Health; PBS: phosphate-buffered saline; PCR: polymerase chain reaction; PLME: Poisson linear mixed effect; PPROM: preterm premature rupture of membranes; rRNA: ribosomal RNA; SDI: Shannon Diversity Index; ZINBLME: zero-inflated negative binomial mixed-effect.

\section{Competing interests}

The authors declare that they have no competing interests.

\section{Authors' contributions}

RR, SSH, PG, AT and JR conceived the study. RR, SSH, JB, PC, JM and TC performed the clinical sampling and samples management. DWF performed DNA extractions, 165 rRNA gene amplifications and sequencing. DWF, PG and JR processed the sequence data. PG and AT performed the statistical analyses. RR, SSH, PG, AT and JR wrote the manuscript. All authors read and approved the final manuscript.

\section{Acknowledgements}

This work was funded, in part, by the Eunice Kennedy Shriver National Institute of Child Health and Human Development, $\mathrm{NIH}, \mathrm{DHHS}$. The authors wish to acknowledge the contributions of the patients who volunteered for these studies, the medical and healthcare personnel involved in the research effort, and colleagues who contributed to the discussions which eventually led to the conduct of the study. We are particularly grateful to Dr. Sharon Hillier of the University of Pittsburgh, Dr. Jack Sobel of Wayne State University, Dr. Ronald Lamont of the University of Southern Denmark, Dr. David Relman of Stanford University, Dr. Sorin Draghici of Wayne State University.

\section{Author details}

'Perinatology Research Branch, Program for Perinatal Research and Obstetrics, Division of Intramural Research, Eunice Kennedy Shriver National
Institute of Child Health and Human Development, NIH, Bethesda, MD, USA. ${ }^{2}$ Department of Obstetrics and Gynecology, University of Michigan, 1500 East Medical Center Drive, Ann Arbor, MI 48109, USA. ${ }^{3}$ Department of Epidemiology and Biostatistics, Michigan State University, Room B601, 909 Fee Road, East Lansing, MI 48824, USA. ${ }^{4}$ Department of Obstetrics and Gynecology, Wayne State University School of Medicine, 540 E Canfield St, Detroit, Ml 48201, USA. ${ }^{5}$ Institute for Genome Sciences, University of Maryland School of Medicine, 801 West Baltimore Street, Baltimore, MD 21201, USA. ${ }^{6}$ Department of Microbiology and Immunology, University of Maryland School of Medicine, 685 W Baltimore St \#480, Baltimore, MD 21201, USA. 'Hutzel Women's Hospital, Detroit Medical Center, 3990 John R, Detroit, MI 48201, USA.

Received: 2 March 2014 Accepted: 4 April 2014

Published: 27 May 2014

\section{References}

1. World Health Organization: Born Too Soon: The Global Action Report in Preterm Birth. Geneva: 2012

2. Beck S, Wojdyla D, Say L, Betran AP, Merialdi M, Requejo JH, Rubens C, Menon R, Van Look PF: The worldwide incidence of preterm birth: a systematic review of maternal mortality and morbidity. Bull World Health Organ 2010, 88:31-38.

3. Premature Birth. [www.marchofdimes.com/peristats/Peristats.aspx]

4. Hamilton BE, Martin JA, Ventura SJ: Births: preliminary data for 2012. Natl Vital Stat Rep 2012, 62:1-20.

5. Goldenberg RL, McClure EM: The epidemiology of preterm birth. In Preterm Birth: Prevention and Management. Edited by Berguella V. Oxford: Willey-Blackwell; 2010:22-38.

6. Muglia $\sqcup$, Katz M: The enigma of spontaneous preterm birth. N Engl J Med 2010, 362:529-535.

7. Blencowe H, Cousens S, Oestergaard MZ, Chou D, Moller AB, Narwal R, Adler A, Vera Garcia C, Rohde S, Say L, Lawn JE: National, regional, and worldwide estimates of preterm birth rates in the year 2010 with time trends since 1990 for selected countries: a systematic analysis and implications. Lancet 2012, 379:2162-2172.

8. Hamilton BE, Hoyert DL, Martin JA, Strobino DM, Guyer B: Annual summary of vital statistics: 2010-2011. Pediatrics 2013, 131:548-558.

9. lams JD, Romero R, Culhane JF, Goldenberg RL: Primary, secondary, and tertiary interventions to reduce the morbidity and mortality of preterm birth. Lancet 2008, 371:164-175.

10. Romero R, Espinoza J, Chaiworapongsa T, Kalache K: Infection and prematurity and the role of preventive strategies. Semin Neonatol 2002, 7:259-274.

11. Romero R, Yeo L, Miranda J, Hassan SS, Conde-Agudelo A, Chaiworapongsa T: A blueprint for the prevention of preterm birth: vaginal progesterone in women with a short cervix. J Perinat Med 2013, 41:27-44.

12. Behrman RE, Butler AS: Social costs of preterm birth. In Preterm Birth: Causes, Consequences and Prevention. Edited by Behrman RE, Butler AS, Policy CoUPBaAHOBoHS. Washington, D.C: National Academies Press; 2007:398-432.

13. Russell RB, Green NS, Steiner CA, Meikle S, Howse JL, Poschman K, Dias T, Potetz L, Davidoff MJ, Damus K, Petrini JR: Cost of hospitalization for preterm and low birth weight infants in the United States. Pediatrics 2007, 120:e1-9.

14. March of Dimes: The Impact of Premature Birth on Society. Available at: http://www.marchofdimes.com/mission/the-economic-and-societal-costs.aspx.

15. Goldenberg RL, Culhane JF, lams JD, Romero R: Epidemiology and causes of preterm birth. Lancet 2008, 371:75-84.

16. Romero R, Mazor M, Munoz H, Gomez R, Galasso M, Sherer DM: The preterm labor syndrome. Ann N Y Acad Sci 1994, 734:414-429.

17. Romero R, Espinoza J, Kusanovic JP, Gotsch F, Hassan S, Erez O, Chaiworapongsa T, Mazor M: The preterm parturition syndrome. BLOG 2006, 113(Suppl 3):17-42.

18. Romero R, Mazor M, Wu YK, Sirtori M, Oyarzun E, Mitchell MD, Hobbins JC: Infection in the pathogenesis of preterm labor. Semin Perinatol 1988 12:262-279.

19. Romero R, Sirtori M, Oyarzun E, Avila C, Mazor M, Callahan R, Sabo V, Athanassiadis AP, Hobbins JC: Infection and labor. V. Prevalence, microbiology, and clinical significance of intraamniotic infection in 
women with preterm labor and intact membranes. Am J Obstet Gynecol 1989, 161:817-824.

20. Romero R, Gomez R, Chaiworapongsa T, Conoscenti G, Kim JC, Kim YM: The role of infection in preterm labour and delivery. Paediatr Perinat Epidemiol 2001, 15(Suppl 2):41-56.

21. Bobitt JR, Hayslip CC, Damato JD: Amniotic fluid infection as determined by transabdominal amniocentesis in patients with intact membranes in premature labor. Am J Obstet Gynecol 1981, 140:947-952.

22. Wahbeh CJ, Hill GB, Eden RD, Gall SA: Intra-amniotic bacterial colonization in premature labor. Am J Obstet Gynecol 1984, 148:739-743.

23. Gravett MG, Hummel D, Eschenbach DA, Holmes KK: Preterm labor associated with subclinical amniotic fluid infection and with bacterial vaginosis. Obstet Gynecol 1986, 67:229-237.

24. Leigh J, Garite TJ: Amniocentesis and the management of premature labor. Obstet Gynecol 1986, 67:500-506.

25. Bruner JP, Elliott JP, Kilbride HW, Garite TJ, Knox GE: Candida chorioamnionitis diagnosed by amniocentesis with subsequent fetal infection. Am J Perinatol 1986, 3:213-218.

26. Romero R, Mazor M: Infection and preterm labor. Clin Obstet Gynecol 1988, 31:553-584.

27. Romero R, Quintero R, Oyarzun E, Wu YK, Sabo V, Mazor M, Hobbins JC: Intraamniotic infection and the onset of labor in preterm premature rupture of the membranes. Am J Obstet Gynecol 1988, 159:661-666.

28. Silver HM, Sperling RS, St Clair PJ, Gibbs RS: Evidence relating bacterial vaginosis to intraamniotic infection. Am J Obstet Gynecol 1989, 161:808-812.

29. Watts DH, Krohn MA, Hillier SL, Eschenbach DA: The association of occult amniotic fluid infection with gestational age and neonatal outcome among women in preterm labor. Obstet Gynecol 1992, 79:351-357.

30. Romero R, Salafia CM, Athanassiadis AP, Hanaoka S, Mazor M, Sepulveda W Bracken MB: The relationship between acute inflammatory lesions of the preterm placenta and amniotic fluid microbiology. Am J Obstet Gynecol 1992, 166:1382-1388.

31. Gibbs RS: Chorioamnionitis and bacterial vaginosis. Am J Obstet Gynecol 1993, 169:460-462

32. Sherman DJ, Tovbin J, Lazarovich T, Avrech O, Reif R, Hoffmann S, Caspi E, Boldur I: Chorioamnionitis caused by gram-negative bacteria as an etiologic factor in preterm birth. Eur J Clin Microbiol Infect Dis 1997, 16:417-423

33. Yoon $\mathrm{BH}$, Chang JW, Romero R: Isolation of Ureaplasma urealyticum from the amniotic cavity and adverse outcome in preterm labor. Obstet Gynecol 1998, 92:77-82.

34. Yoon BH, Romero R, Kim M, Kim EC, Kim T, Park JS, Jun JK: Clinical implications of detection of Ureaplasma urealyticum in the amniotic cavity with the polymerase chain reaction. Am J Obstet Gynecol 2000, 183:1130-1137.

35. Andrews WW, Hauth JC, Goldenberg RL: Infection and preterm birth. Am J Perinatol 2000, 17:357-365

36. Jacobsson B, Mattsby-Baltzer I, Andersch B, Bokstrom H, Holst RM, Wennerholm $U B$, Hagberg $\mathrm{H}$ : Microbial invasion and cytokine response in amniotic fluid in a Swedish population of women in preterm labor. Acta Obstet Gynecol Scand 2003, 82:120-128.

37. Novy MJ, Duffy L, Axthelm MK, Sadowsky DW, Witkin SS, Gravett MG Cassell GH, Waites KB: Ureaplasma parvum or Mycoplasma hominis as sole pathogens cause chorioamnionitis, preterm delivery, and fetal pneumonia in rhesus macaques. Reprod Sci 2009, 16:56-70.

38. Benirschke K: Routes and types of infection in the fetus and the newborn. AMA J Dis Child 1960, 99:714-721.

39. Blanc WA: Pathways of fetal and early neonatal infection. Viral placentitis, bacterial and fungal chorioamnionitis. J Pediatr 1961, 59:473-496.

40. Martius J, Eschenbach DA: The role of bacterial vaginosis as a cause of amniotic fluid infection, chorioamnionitis and prematurity-a review. Arch Gynecol Obstet 1990, 247:1-13.

41. Hillier SL, Nugent RP, Eschenbach DA, Krohn MA, Gibbs RS, Martin DH, Cotch MF, Edelman R, Pastorek JG 2nd, Rao AV, McNellis D, Regan JA, Carey JC, Klebanoff MA: Association between bacterial vaginosis and preterm delivery of a low-birth-weight infant. The Vaginal Infections and Prematurity Study Group. N Engl J Med 1995, 333:1737-1742.

42. Chaim W, Mazor M, Leiberman JR: The relationship between bacterial vaginosis and preterm birth. A review. Arch Gynecol Obstet 1997 259:51-58.
43. Hitti J, Hillier SL, Agnew KJ, Krohn MA, Reisner DP, Eschenbach DA: Vaginal indicators of amniotic fluid infection in preterm labor. Obstet Gynecol 2001, 97:211-219.

44. Goncalves LF, Chaiworapongsa T, Romero R: Intrauterine infection and prematurity. Ment Retard Dev Disabil Res Rev 2002, 8:3-13.

45. Racicot K, Cardenas I, Wunsche V, Aldo P, Guller S, Means RE, Romero R, Mor G: Viral infection of the pregnant cervix predisposes to ascending bacterial infection. J Immunol 2013, 191:934-941.

46. Minkoff H, Grunebaum A, Feldman J, Cummings M, McCormack WM: Relationship of vaginal $\mathrm{pH}$ and Papanicolaou smear results to vaginal flora and pregnancy outcome. Int J Gynaecol Obstet 1987, 25:17-23.

47. Cotch MF, Pastorek JG 2nd, Nugent RP, Hillier SL, Gibbs RS, Martin DH, Eschenbach DA, Edelman R, Carey JC, Regan JA, Krohn MA, Klebanoff MA, Rao AV, Rhoads GG: Trichomonas vaginalis associated with low birth weight and preterm delivery. The Vaginal Infections and Prematurity Study Group. Sex Transm Dis 1997, 24:353-360.

48. Andrews WW, Klebanoff MA, Thom EA, Hauth JC, Carey JC, Meis PJ, Caritis SN, Leveno KJ, Wapner RJ, Varner MW, lams JD, Moawad A, Miodovnik M, Sibai B, Dombrowski M, Langer O, O'Sullivan MJ: Midpregnancy genitourinary tract infection with Chlamydia trachomatis: association with subsequent preterm delivery in women with bacterial vaginosis and Trichomonas vaginalis. Am J Obstet Gynecol 2006, 194:493-500.

49. Gravett MG, Nelson HP, DeRouen T, Critchlow C, Eschenbach DA, Holmes KK: Independent associations of bacterial vaginosis and Chlamydia trachomatis infection with adverse pregnancy outcome. JAMA 1986 256:1899-1903.

50. Romero R, Mazor M, Oyarzun E, Sirtori M, Wu YK, Hobbins JC: Is genital colonization with Mycoplasma hominis or Ureaplasma urealyticum associated with prematurity/low birth weight? Obstet Gynecol 1989, 73:532-536

51. Hillier SL, Krohn MA, Nugent RP, Gibbs RS: Characteristics of three vaginal flora patterns assessed by gram stain among pregnant women. Vaginal Infections and Prematurity Study Group. Am J Obstet Gynecol 1992, 166:938-944.

52. Holst E, Goffeng AR, Andersch B: Bacterial vaginosis and vaginal microorganisms in idiopathic premature labor and association with pregnancy outcome. J Clin Microbiol 1994, 32:176-186.

53. Meis PJ, Goldenberg RL, Mercer B, Moawad A, Das A, McNellis D, Johnson F, lams JD, Thom E, Andrews WW: The preterm prediction study: significance of vaginal infections. National Institute of Child Health and Human Development Maternal-Fetal Medicine Units Network. Am J Obstet Gynecol 1995, 173:1231-1235.

54. Krohn MA, Hillier SL, Nugent RP, Cotch MF, Carey JC, Gibbs RS, Eschenbach DA: The genital flora of women with intraamniotic infection. Vaginal Infection and Prematurity Study Group. J Infect Dis 1995, 171:1475-1480.

55. Andrews WW, Goldenberg RL, Hauth JC: Preterm labor: emerging role of genital tract infections. Infect Agents Dis 1995, 4:196-211.

56. Goldenberg RL, Thom E, Moawad AH, Johnson F, Roberts J, Caritis SN: The preterm prediction study: fetal fibronectin, bacterial vaginosis, and peripartum infection. NICHD Maternal Fetal Medicine Units Network. Obstet Gynecol 1996, 87:656-660.

57. Goldenberg RL, Klebanoff MA, Nugent R, Krohn MA, Hillier S, Andrews WW: Bacterial colonization of the vagina during pregnancy in four ethnic groups. Vaginal Infections and Prematurity Study Group. Am J Obstet Gynecol 1996, 174:1618-1621

58. Jacobsson B, Pernevi P, Chidekel L, Jorgen Platz-Christensen J: Bacterial vaginosis in early pregnancy may predispose for preterm birth and postpartum endometritis. Acta Obstet Gynecol Scand 2002, 81:1006-1010.

59. Leitich $H$, Bodner-Adler B, Brunbauer M, Kaider A, Egarter C, Husslein P: Bacterial vaginosis as a risk factor for preterm delivery: a meta-analysis. Am J Obstet Gynecol 2003, 189:139-147.

60. Romero R, Chaiworapongsa T, Kuivaniemi H, Tromp G: Bacterial vaginosis, the inflammatory response and the risk of preterm birth: a role for genetic epidemiology in the prevention of preterm birth. Am J Obstet Gynecol 2004, 190:1509-1519.

61. Klebanoff MA, Hillier SL, Nugent RP, MacPherson CA, Hauth JC, Carey JC, Harper M, Wapner RJ, Trout W, Moawad A, Leveno KJ, Miodovnik M, Sibai BM, Vandorsten JP, Dombrowski MP, O'Sullivan MJ, Varner M, Langer O: Is bacterial vaginosis a stronger risk factor for preterm birth when it is diagnosed earlier in gestation? Am J Obstet Gynecol 2005, 192:470-477. 
62. Vogel I, Thorsen P, Hogan VK, Schieve LA, Jacobsson B, Ferre CD: The joint effect of vaginal Ureaplasma urealyticum and bacterial vaginosis on adverse pregnancy outcomes. Acta Obstet Gynecol Scand 2006, 85:778-785.

63. Donders GG, Van Calsteren K, Bellen G, Reybrouck R, Van den Bosch T, Riphagen I, Van Lierde S: Predictive value for preterm birth of abnormal vaginal flora, bacterial vaginosis and aerobic vaginitis during the first trimester of pregnancy. BJOG 2009, 116:1315-1324.

64. Lee SE, Romero R, Kim EC, Yoon BH: A high Nugent score but not a positive culture for genital mycoplasmas is a risk factor for spontaneous preterm birth. J Matern Fetal Neonatal Med 2009, 22:212-217.

65. Lamont RF, Taylor-Robinson D: The role of bacterial vaginosis, aerobic vaginitis, abnormal vaginal flora and the risk of preterm birth. BJOG 2010, 117:119-120. author reply 120-121.

66. Donders GG, Riphagen I, van den Bosch T: Abnormal vaginal flora, cervical length and preterm birth. Ultrasound Obstet Gynecol 2000, 16:496-497.

67. Donders GG, Van Calsteren C, Bellen G, Reybrouck R, Van den Bosch T, Riphagen I, Van Lierde S: Association between abnormal vaginal flora and cervical length as risk factors for preterm birth. Ultrasound Obstet Gynecol 2010. doi:10.1002/uog.7568.

68. Ward DM, Weller $R$, Bateson MM: $16 \mathrm{~s}$ ribosomal-Rna sequences reveal numerous uncultured microorganisms in a natural community. Nature 1990, 345:63-65.

69. Eckburg PB, Bik EM, Bernstein CN, Purdom E, Dethlefsen L, Sargent M, Gill $\mathrm{SR}$, Nelson KE, Relman DA: Diversity of the human intestinal microbial flora. Science 2005, 308:1635-1638.

70. Backhed F, Ley RE, Sonnenburg JL, Peterson DA, Gordon Jl: Host-bacterial mutualism in the human intestine. Science 2005, 307:1915-1920.

71. Turnbaugh PJ, Ley RE, Hamady M, Fraser-Liggett CM, Knight R, Gordon J: The human microbiome project. Nature 2007, 449:804-810.

72. Petrosino JF, Highlander S, Luna RA, Gibbs RA, Versalovic J: Metagenomic pyrosequencing and microbial identification. Clin Chem 2009, 55:856-866.

73. Nih HMP, Working Group, Peterson J, Garges S, Giovanni M, Mclnnes P, Wang L, Schloss JA, Bonazzi V, McEwen JE, Wetterstrand KA, Deal C, Baker CC, Di Francesco V, Howcroft TK, Karp RW, Lunsford RD, Wellington CR, Belachew T, Wright M, Giblin C, David H, Mills M, Salomon R, Mullins C, Akolkar B, Begg L, Davis C, Grandison L, Humble M, Khalsa J, et al: The NIH Human Microbiome Project. Genome Res 2009, 19:2317-2323.

74. Nelson KE, Weinstock GM, Highlander SK, Worley KC, Creasy HH, Wortman $J R$, Rusch DB, Mitreva M, Sodergren E, Chinwalla AT, Feldgarden M, Gevers D, Haas BJ, Madupu R, Ward DV, Birren BW, Gibbs RA, Methe B, Petrosino JF, Strausberg RL, Sutton GG, White OR, Wilson RK, Durkin S, Giglio MG, Gujja S, Howarth C, Kodira CD, Kyrpides N, Mehta T, et al: A catalog of reference genomes from the human microbiome. Science 2010, 328:994-999.

75. Qin J, Li R, Raes J, Arumugam M, Burgdorf KS, Manichanh C, Nielsen T, Pons N, Levenez F, Yamada T, Mende DR, Li J, Xu J, Li S, Li D, Cao J, Wang B, Liang $H$, Zheng H, Xie Y, Tap J, Lepage P, Bertalan M, Batto JM, Hansen T, Le Paslier D, Linneberg A, Nielsen HB, Pelletier $E$, Renault $P$, et al: A human gut microbial gene catalogue established by metagenomic sequencing. Nature 2010, 464:59-65.

76. Cho I, Blaser MJ: The human microbiome: at the interface of health and disease. Nat Rev Genet 2012, 13:260-270.

77. Relman DA: Microbiology: learning about who we are. Nature 2012, 486:194-195.

78. Pavlova SI, Kilic AO, Kilic SS, So JS, Nader-Macias ME, Simoes JA, Tao L: Genetic diversity of vaginal lactobacilli from women in different countries based on 16S rRNA gene sequences. J Appl Microbio/ 2002, 92:451-459.

79. Verhelst $R$, Verstraelen $H$, Claeys $G$, Verschraegen $G$, Delanghe J, Van Simaey L, De Ganck C, Temmerman M, Vaneechoutte M: Cloning of 16S rRNA genes amplified from normal and disturbed vaginal microflora suggests a strong association between Atopobium vaginae. Gardnerella vaginalis and bacterial vaginosis. BMC Microbiol 2004, 4:16.

80. Zhou X, Bent SJ, Schneider MG, Davis CC, Islam MR, Forney L: Characterization of vaginal microbial communities in adult healthy women using cultivation-independent methods. Microbiol 2004 150:2565-2573.

81. Verstraelen $H$, Verhelst $R$, Claeys $G$, Temmerman M, Vaneechoutte $M$ : Culture-independent analysis of vaginal microflora: the unrecognized association of Atopobium vaginae with bacterial vaginosis. Am J Obstet Gynecol 2004, 191:1130-1132
82. Fredricks DN, Fiedler TL, Marrazzo JM: Molecular identification of bacteria associated with bacterial vaginosis. N Engl J Med 2005, 353:1899-1911.

83. Fredricks DN, Marrazzo JM: Molecular methodology in determining vaginal flora in health and disease: its time has come. Curr Infect Dis Rep 2005, 7:463-470

84. Hill JE, Goh SH, Money DM, Doyle M, Li A, Crosby WL, Links M, Leung A Chan D, Hemmingsen SM: Characterization of vaginal microflora of healthy, nonpregnant women by chaperonin- 60 sequence-based methods. Am J Obstet Gynecol 2005, 193:682-692.

85. Devillard E, Burton JP, Reid G: Complexity of vaginal microflora as analyzed by PCR denaturing gradient gel electrophoresis in a patient with recurrent bacterial vaginosis. Infect Dis Obstet Gynecol 2005, 13:25-31.

86. Tamrakar R, Yamada T, Furuta I, Cho K, Morikawa M, Yamada H, Sakuragi N, Minakami $\mathrm{H}$ : Association between Lactobacillus species and bacterial vaginosis-related bacteria, and bacterial vaginosis scores in pregnant Japanese women. BMC Infect Dis 2007, 7:128.

87. Oakley BB, Fiedler TL, Marrazzo JM, Fredricks DN: Diversity of human vaginal bacterial communities and associations with clinically defined bacterial vaginosis. Appl Environ Microbiol 2008, 74:4898-4909.

88. Brotman RM, Ravel J: Ready or not: the molecular diagnosis of bacterial vaginosis. Clin Infect Dis 2008, 47:44-46.

89. Trama JP, Pascal KE, Zimmerman J, Self MJ, Mordechai E, Adelson ME: Rapid detection of Atopobium vaginae and association with organisms implicated in bacterial vaginosis. Mol Cell Probes 2008, 22:96-102.

90. Menard JP, Fenollar F, Henry M, Bretelle F, Raoult D: Molecular quantification of Gardnerella vaginalis and Atopobium vaginae loads to predict bacterial vaginosis. Clin Infect Dis 2008, 47:33-43.

91. Marrazzo JM, Thomas KK, Fiedler TL, Ringwood K, Fredricks DN: Relationship of specific vaginal bacteria and bacterial vaginosis treatment failure in women who have sex with women. Ann Intern Med 2008, 149:20-28.

92. Yamamoto T, Zhou X, Williams CJ, Hochwalt A, Forney L: Bacterial populations in the vaginas of healthy adolescent women. $J$ Pediatr Adolesc Gynecol 2009, 22:11-18.

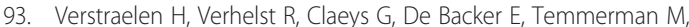
Vaneechoutte M: Longitudinal analysis of the vaginal microflora in pregnancy suggests that $L$. crispatus promotes the stability of the normal vaginal microflora and that L. gasseri and/or L. iners are more conducive to the occurrence of abnormal vaginal microflora. BMC Microbiol 2009, 9:116.

94. Lamont RF, Sobel JD, Akins RA, Hassan SS, Chaiworapongsa T, Kusanovic JP, Romero R: The vaginal microbiome: new information about genital tract flora using molecular based techniques. BJOG 2011, 118:533-549.

95. Ravel J, Gajer P, Abdo Z, Schneider GM, Koenig SS, McCulle SL, Karlebach S, Gorle R, Russell J, Tacket CO, Brotman RM, Davis CC, Ault K, Peralta L, Forney $\mathrm{LJ}$ : Vaginal microbiome of reproductive-age women. Proc Natl Acad Sci U S A 2011, 108(Suppl 1):4680-4687.

96. Aagaard K, Riehle K, Ma J, Segata N, Mistretta TA, Coarfa C, Raza S, Rosenbaum S, Van den Veyver I, Milosavljevic A, Gevers D, Huttenhower C, Petrosino J, Versalovic J: A metagenomic approach to characterization of the vaginal microbiome signature in pregnancy. PLoS One 2012, 7:e36466.

97. Romero R, Hassan SS, Gajer P, Tarca AL, Fadrosh DW, Nikita L, Galuppi M, Lamont RF, Chaemsaithong P, Miranda J, Chaiworapongsa T, Ravel J: The composition and stability of the vaginal microbiota of normal pregnant women is different from that of non-pregnant women. Microbiome 2014, 2:4

98. Pacora P, Chaiworapongsa T, Maymon E, Kim YM, Gomez R, Yoon BH, Ghezzi F, Berry SM, Qureshi F, Jacques SM, Kim JC, Kadar N, Romero R: Funisitis and chorionic vasculitis: the histological counterpart of the fetal inflammatory response syndrome. J Matern Fetal Neonatal Med 2002 11:18-25.

99. Kingdom J: Placental diagnostic criteria and clinical correlation-a workshop report. Placenta 2005, 26(Suppl A):S114-117.

100. Redline RW: Inflammatory responses in the placenta and umbilical cord. Semin Fetal Neonatal Med 2006, 11:296-301.

101. Forney L, Gajer P, Williams CJ, Schneider GM, Koenig SS, McCulle SL, Karlebach S, Brotman RM, Davis CC, Ault K, Ravel J: Comparison of selfcollected and physician-collected vaginal swabs for microbiome analysis. J Clin Microbiol 2010, 48:1741-1748.

102. Yuan S, Cohen DB, Ravel J, Abdo Z, Forney LJ: Evaluation of methods for the extraction and purification of DNA from the human microbiome. PLoS One 2012, 7:e33865. 
103. Frank JA, Reich Cl, Sharma S, Weisbaum JS, Wilson BA, Olsen GJ: Critical evaluation of two primers commonly used for amplification of bacterial $16 S$ rRNA genes. Appl Environ Microbiol 2008, 74:2461-2470.

104. Human Microbiome Project Consortium: Structure, function and diversity of the healthy human microbiome. Nature 2012, 486:207-214

105. Caporaso JG, Kuczynski J, Stombaugh J, Bittinger K, Bushman FD, Costello EK, Fierer N, Pena AG, Goodrich JK, Gordon Jl, Huttley GA, Kelley ST, Knights D, Koenig JE, Ley RE, Lozupone CA, McDonald D, Muegge BD, Pirrung M, Reeder J, Sevinsky JR, Turnbaugh PJ, Walters WA, Widmann J, Yatsunenko T, Zaneveld J, Knight R: QIIME allows analysis of high-throughput community sequencing data. Nat Methods 2010, 7:335-336.

106. Edgar RC: Search and clustering orders of magnitude faster than BLAST. Bioinformatics 2010, 26:2460-2461.

107. Edgar RC, Haas BJ, Clemente JC, Quince C, Knight R: UCHIME improves sensitivity and speed of chimera detection. Bioinformatics 2011, 27:2194-2200

108. Matsen FA, Kodner RB, Armbrust EV: Pplacer: linear time maximumlikelihood and Bayesian phylogenetic placement of sequences onto a fixed reference tree. BMC Bioinforma 2010, 11:538.

109. Lin J: Divergence measures based on the Shannon entropy. IEEE Trans Information Theory 1991, 37:145-151.

110. Gajer P, Brotman RM, Bai G, Sakamoto J, Schutte UM, Zhong X, Koenig SS, Fu L, Ma ZS, Zhou X, Abdo Z, Forney LJ, Ravel J: Temporal dynamics of the human vaginal microbiota. Sci Trans/ Med 2012, 4:132ra152.

111. Lambert D: Zero-Inflated Poisson regression, with an application to defects in manufacturing. Technometrics 1992, 34:1-14.

112. Littell CA, Milliken GA, Stroup WW, Wolfinger RD, Schabenberger O: Nonlinear mixed models. In SAS for Mixed Models. 2nd edition. Edited by Littell CA, Milliken GA, Stroup WW, Wolfinger RD, Schabenberger O. Cary, NY: SAS Institute Inc; 2006:567-635.

113. Zero-Inflated Poisson and Zero-Inflated Negative Binomial Models Using the COUNTREG Procedure. Available at: http://www2.sas.com/proceedings/ forum2008/322-2008.pdf

114. Fredricks DN, Fiedler TL, Thomas KK, Oakley BB, Marrazzo JM: Targeted PCR for detection of vaginal bacteria associated with bacterial vaginosis. J Clin Microbiol 2007, 45:3270-3276.

115. Yoon BH, Romero R, Moon JB, Shim SS, Kim M, Kim G, Jun JK: Clinical significance of intra-amniotic inflammation in patients with preterm labor and intact membranes. Am J Obstet Gynecol 2001, 185:1130-1136.

116. Romero R, Lockwood CJ: Pathogenesis of spontaneous preterm labor. In Creasy and Resnik's Maternal-Fetal Medicine: Principles and Practice. 6th edition. Edited by Creasy RK, Resnik R, lams J. Philadelphia: Elsevier; 2009:521-543.

117. Hillier SL, Krohn MA, Cassen E, Easterling TR, Rabe LK, Eschenbach DA: The role of bacterial vaginosis and vaginal bacteria in amniotic fluid infection in women in preterm labor with intact fetal membranes. Clin Infect Dis 1995, 20(Suppl 2):S276-278.

118. DiGiulio DB, Romero R, Amogan HP, Kusanovic JP, Bik EM, Gotsch F, Kim CJ, Erez O, Edwin S, Relman DA: Microbial prevalence, diversity and abundance in amniotic fluid during preterm labor: a molecular and culture-based investigation. PLOS One 2008, 3:e3056.

119. DiGiulio DB, Romero R, Kusanovic JP, Gomez R, Kim CJ, Seok KS, Gotsch F, Mazaki-Tovi S, Vaisbuch E, Sanders K, Bik EM, Chaiworapongsa T, Oyarzun E, Relman DA: Prevalence and diversity of microbes in the amniotic fluid, the fetal inflammatory response, and pregnancy outcome in women with preterm pre-labor rupture of membranes. Am J Reprod Immunol 2010, 64:38-57.

120. Oh KJ, Lee SE, Jung H, Kim G, Romero R, Yoon BH: Detection of ureaplasmas by the polymerase chain reaction in the amniotic fluid of patients with cervical insufficiency. J Perinat Med 2010, 38:261-268.

121. Donders GG, Vereecken A, Bosmans E, Dekeersmaecker A, Salembier G, Spitz $B$ : Definition of a type of abnormal vaginal flora that is distinct from bacterial vaginosis: aerobic vaginitis. BLOG 2002, 109:34-43.

122. Donders G, Bellen G, Rezeberga D: Aerobic vaginitis in pregnancy. BLOG 2011, 118:1163-1170.

123. Hay PE, Lamont RF, Taylor-Robinson D, Morgan DJ, Ison C, Pearson J: Abnormal bacterial colonisation of the genital tract and subsequent preterm delivery and late miscarriage. BMJ 1994, 308:295-298.

124. Llahi-Camp JM, Rai R, Ison C, Regan L, Taylor-Robinson D: Association of bacterial vaginosis with a history of second trimester miscarriage. Hum Reprod 1996, 11:1575-1578.
125. Ralph SG, Rutherford AJ, Wilson JD: Influence of bacterial vaginosis on conception and miscarriage in the first trimester: cohort study. BMJ 1999, 319:220-223.

126. Donders GG, Van Bulck B, Caudron J, Londers L, Vereecken A, Spitz B: Relationship of bacterial vaginosis and mycoplasmas to the risk of spontaneous abortion. Am J Obstet Gynecol 2000, 183:431-437.

127. Oakeshott P, Hay P, Hay S, Steinke F, Rink E, Kerry S: Association between bacterial vaginosis or chlamydial infection and miscarriage before 16 weeks' gestation: prospective community based cohort study. BMJ 2002, 325:1334.

128. Leitich $\mathrm{H}$, Kiss $\mathrm{H}$ : Asymptomatic bacterial vaginosis and intermediate flora as risk factors for adverse pregnancy outcome. Best Pract Res Clin Obstet Gynaecol 2007, 21:375-390.

129. Eschenbach DA, Gravett MG, Chen KC, Hoyme UB, Holmes KK: Bacterial vaginosis during pregnancy. An association with prematurity and postpartum complications. Scan J Urol Nephrol Suppl 1984, 86:213-222.

130. McGregor JA: Prevention of preterm birth: new initiatives based on microbial-host interactions. Obstet Gynecol Surv 1988, 43:1-14.

131. Hauth JC, Macpherson C, Carey JC, Klebanoff MA, Hillier SL, Ernest JM, Leveno K, Wapner R, Varner M, Trout W, Moawad A, Sibai B: Early pregnancy threshold vaginal $\mathrm{pH}$ and Gram stain scores predictive of subsequent preterm birth in asymptomatic women. Am J Obstet Gynecol 2003, 188:831-835.

132. Newton ER, Piper J, Peairs W: Bacterial vaginosis and intraamniotic infection. Am J Obstet Gynecol 1997, 176:672-677.

133. Jacobsson B, Mattsby-Baltzer I, Hagberg H: Interleukin-6 and interleukin-8 in cervical and amniotic fluid: relationship to microbial invasion of the chorioamniotic membranes. BJOG 2005, 112:719-724.

134. Goldenberg RL, Culhane JF, Johnson DC: Maternal infection and adverse fetal and neonatal outcomes. Clin Perinatol 2005, 32:523-559.

135. Holst RM, Jacobsson B, Hagberg H, Wennerholm UB: Cervical length in women in preterm labor with intact membranes: relationship to intraamniotic inflammation/microbial invasion, cervical inflammation and preterm delivery. Ultrasound Obstet Gynecol 2006, 28:768-774.

136. Watts DH, Eschenbach DA, Kenny GE: Early postpartum endometritis: the role of bacteria, genital mycoplasmas, and Chlamydia trachomatis. Obstet Gynecol 1989, 73:52-60.

137. Watts DH, Krohn MA, Hillier SL, Eschenbach DA: Bacterial vaginosis as a risk factor for post-cesarean endometritis. Obstet Gynecol 1990, 75:52-58.

138. Newton ER, Prihoda TJ, Gibbs RS: A clinical and microbiologic analysis of risk factors for puerperal endometritis. Obstet Gynecol 1990, 75:402-406.

139. Clark $P$, Kurtzer T, Duff $P$ : Role of bacterial vaginosis in peripartum infections. Infect Dis Obstet Gynecol 1994, 2:179-183.

140. Dammann O, Leviton A: Does prepregnancy bacterial vaginosis increase a mother's risk of having a preterm infant with cerebral palsy? Dev Med Child Neurol 1997, 39:836-840.

141. Denney JM, Culhane JF: Bacterial vaginosis: a problematic infection from both a perinatal and neonatal perspective. Semin Fetal Neonatal Med 2009, 14:200-203.

142. Laxmi U, Agrawal S, Raghunandan C, Randhawa VS, Saili A: Association of bacterial vaginosis with adverse fetomaternal outcome in women with spontaneous preterm labor: a prospective cohort study. J Matern Fetal Neonatal Med 2012, 25:64-67.

143. Carey JC, Klebanoff MA, Hauth JC, Hillier SL, Thom EA, Ernest JM, Heine RP, Nugent RP, Fischer ML, Leveno KJ, Wapner R, Varner M: Metronidazole to prevent preterm delivery in pregnant women with asymptomatic bacterial vaginosis. National Institute of Child Health and Human Development Network of Maternal-Fetal Medicine Units. N Engl J Med 2000, 342:534-540

144. Klebanoff MA, Carey JC, Hauth JC, Hillier SL, Nugent RP, Thom EA, Ernest JM, Heine RP, Wapner RJ, Trout W, Moawad A, Leveno KJ, Miodovnik M, Sibai BM, Van Dorsten JP, Dombrowski MP, O'Sullivan MJ, Varner M, Langer O, McNellis D, Roberts JM: Failure of metronidazole to prevent preterm delivery among pregnant women with asymptomatic Trichomonas vaginalis infection. N Engl J Med 2001, 345:487-493.

145. Kekki M, Kurki T, Pelkonen J, Kurkinen-Raty M, Cacciatore B, Paavonen J: Vaginal clindamycin in preventing preterm birth and peripartal infections in asymptomatic women with bacterial vaginosis: a randomized, controlled trial. Obstet Gynecol 2001, 97:643-648.

146. Nygren P, Fu R, Freeman M, Bougatsos C, Klebanoff M, Guise JM: Evidence on the benefits and harms of screening and treating pregnant women 
who are asymptomatic for bacterial vaginosis: an update review for the U.S. Preventive Services Task Force. Ann Intern Med 2008, 148:220-233.

147. Lamont RF, Nhan-Chang CL, Sobel JD, Workowski K, Conde-Agudelo A, Romero $\mathrm{R}$ : Treatment of abnormal vaginal flora in early pregnancy with clindamycin for the prevention of spontaneous preterm birth: a systematic review and metaanalysis. Am J Obstet Gynecol 2011, 205:177-190.

148. Brocklehurst P, Gordon A, Heatley E, Milan SJ: Antibiotics for treating bacterial vaginosis in pregnancy. Cochrane Database Syst Rev 2013, 1, CD000262.

149. Macones GA, Parry S, Elkousy M, Clothier B, Ural SH, Strauss JF 3rd: A polymorphism in the promoter region of TNF and bacterial vaginosis: preliminary evidence of gene-environment interaction in the etiology of spontaneous preterm birth. Am J Obstet Gynecol 2004, 190:1504-1508. discussion 1503A.

150. Gomez LM, Sammel MD, Appleby DH, Elovitz MA, Baldwin DA, Jeffcoat MK, Macones GA, Parry S: Evidence of a gene-environment interaction that predisposes to spontaneous preterm birth: a role for asymptomatic bacterial vaginosis and DNA variants in genes that control the inflammatory response. Am J Obstet Gynecol 2010, 202:e381-386.

151. Genc MR, Onderdonk A: Endogenous bacterial flora in pregnant women and the influence of maternal genetic variation. BJOG 2011, 118:154-163.

152. Redline RW, Faye-Petersen O, Heller D, Qureshi F, Savell V, Vogler C: Amniotic infection syndrome: nosology and reproducibility of placental reaction patterns. Pediatr Pathol Dev 2003, 6:435-448.

153. Elovitz MA, Gajer P, Bastek J, Anglim L, Brown A, Ravel J: The cervicovaginal microbiota is different in women destined to have a preterm birth. Am J Obstet Gynecol 2014, 210:S16-S17.

154. Morgan XC, Huttenhower C: Chapter 12: human microbiome analysis. PLoS Comput Biol 2012, 8:e1002808.

155. Nelson DB, Hanlon A, Nachamkin I, Haggerty C, Mastrogiannis DS, Liu C, Fredricks DN: Early pregnancy changes in bacterial vaginosis-associated bacteria and preterm delivery. Pediatr Perinat Epidemiol 2014, 28:88-96.

156. Wen A, Srinivasan U, Goldberg D, Owen J, Marrs CF, Misra D, Wing DA, Ponnaluri S, Miles-Jay A, Bucholz B, Abbas K, Foxman B: Selected vaginal bacteria and risk of preterm birth: an ecological perspective. J Infect Dis 2014, 209:1087-1094.

doi:10.1186/2049-2618-2-18

Cite this article as: Romero et al.: The vaginal microbiota of pregnant women who subsequently have spontaneous preterm labor and delivery and those with a normal delivery at term. Microbiome 2014 2:18.

\section{Submit your next manuscript to BioMed Central and take full advantage of:}

- Convenient online submission

- Thorough peer review

- No space constraints or color figure charges

- Immediate publication on acceptance

- Inclusion in PubMed, CAS, Scopus and Google Scholar

- Research which is freely available for redistribution 